\title{
COMPARATIVE RESEARCH OF THE RESULTS OF FUNCTIONAL REGIONALIZATION METHODS - BY THE NETWORK OF COMMUTING IN HUNGARY
}

\author{
János PÉNZES ${ }^{\mathrm{a}}$, Gábor PÁLÓCZI ${ }^{\mathrm{b}}$ \\ ${ }^{a}$ University of Debrecen, H-4032 Debrecen, Egyetem tér 1., penzes.janos@science.unideb.hu \\ ${ }^{\mathrm{b}}$ University of Debrecen, H-4032 Debrecen, Egyetem tér 1., paloczig@gmail.com
}

Cite this article: Pénzes, J., Pálóczi, G. (2017) Comparative Research of the Results of Functional Regionalization Methods - By the Network of Commuting in Hungary. Deturope. 9(3): 29-41

\begin{abstract}
The paper deals with the topic of functional regionalization and demonstrates some of the possible delimitation methodologies on the basis of commuting to work dataset provided by the 2011 census in Hungary. The main objective of the study is to compare the results of the different methods on the basis of the resulted territorial divisions, their centres and hinterlands.

The method of local labour systems (LLS), the method of labour market areas (LMA) - called as EURO method - and the CURDS measure are introduced, applied and compared. The results of the calculations clearly demonstrate the different characters of the methods.

The results of the LLS method are characterized by major disparities with an extremely extended Budapest LLS district. The EURO method results in a less extending central region around Budapest, however, the CURDS measure causes the most moderate inequalities among the functional regions with the smallest number of units.

The differing character of the methods can be discovered in the centres as well. LLS centres indicate the polarizing character of the method preferring the largest centres, at the same time it gives possibility to the smaller centres to be delimited. The centres of the EURO method appear with the largest frequency and it gives the possibility that those centres are located in the surroundings of dominant centres. The CURDS measure is the 'strictest' one from this respect. The comparative results drew the attention to the differing character of centres in each part of Hungary.
\end{abstract}

Keywords: commute, employment centre, local labour systems, labour market area, territorial division

\section{INTRODUCTION}

\section{The concepts and definitions of functional regions}

The delineation of territorial units based on functional relations is an increasingly exciting and actual issue in regional science, human geography and regional development planning. Formal and functional regions were created during the last decades on the basis of various approaches and methodologies. The term , functional region' has been introduced into human geography by American geographers (e.g. Philbrick, 1957, Nystuen-Dacey, 1961).

In order to study the structure of a given territorial system, an analysis of social-economic movements is required at first (the channels along which movements occur). The movements 
create interactions and flows, networks, nodes and hierarchical organization that as a complex system ultimately forms spatial patterns and surfaces. The concept of ,functional region“ is an abstract spatial feature, which is the reason why there is no sole correct procedure to delimit such regions and why different analyses of the same dataset can provide considerably differing results (Laan \& Schalke, 2001).

Functional regions generally refer to territorial units where intense economic interactions, including the use of services, trade or commuting to work are typical (Karlsson-Olsson, 2006). Labour market interactions are most commonly used in functional region delineations (e.g. travel-to-work flows, particularly with daily periodicity). Commuting to work is regarded as the most frequent and stable regular movement of the population with a daily periodicity (Bujdosó et al., 2013), so these flows are appropriate to represent functional relations. Functional regions based on the daily travel-to-work flows are referred to as local labour market areas (LLMA) or travel-to-work areas (TTWA).

The objective of the delineation of functional regions is to maximize and minimize the ratio of within-region and that of inter-regional flows respectively, so the analysis is based on relational datasets (Haggett, 1965; Klapka et al., 2014). A labour commuting dataset is appropriate from this respect as it generally contains detailed territorial relational values for the employed population (in some cases modifications and corrections are required - Pálóczi et al., 2016). Numerous quantitative methodologies were developed to detect and delineate functional regions, but most of them tend to favour three approaches:

- clustering methods using numerical taxonomy (e.g. Smart, 1974);

- graph theory procedures (e.g. Nystuen \& Dacey, 1961; Karlsson \& Olsson, 2006);

- multistage (or rule-based) procedures (e.g. the approach developed by the Centre for Urban and Regional Development Studies [CURDS] in Newcastle, UK - see Coombes et al., 1986 and Coombes-Bond, 2008 for more information).

In the current analysis, three multistage methods are studied comparatively on the example of Hungary and the focus is on the centres and hinterlands of the functional regions. Due to the limited extent of the paper, only the number of settlements and number of population are used as descriptive statistics.

\section{OBJECTIVES AND METHODS}

\section{Possibilities to delineate functional regions}

Three multistage methods are introduced and applied in the current analysis. The objective of this paper is to highlight the different results of the given methods and their differing 
characteristics assessing their advantages and limitations by the centres and functional regions themselves. The second objective of this study is to position the different results in the spatial pattern of a country and to give a summary about the results according to counties of Hungary (NUTS 3 level). These results may be useful for regional planning activities providing empirical information about the employment centres.

The concept of local labour systems (LLS) is the first methodology that is important to be taken into consideration. The local labour systems of Hungary were delimited for the first time on the basis of the 2001 census dataset as part of a European research project (Radvánszki-Sütő, 2007). The original methodology was modified in the updated investigation including the results for 2011 as well (Pénzes et al., 2015).

As part of this two-step method, labour centres were chosen at first. The settlements with more than 1,000 people employed locally were taken into account. Only those settlements were regarded as centres that attracted at least one settlement from where the majority of the commuters worked in the given centre. In the next phase, the settlements from where more than $10 \%$ of the employees commuted to another centre were removed from the range of centres (exceptions were the settlements mutually attracting each other, in this case centrepairs have been identified while the towns were considered independent centres from where the proportion of people commuting was less than $20 \%$, the number of people employed locally was more than 5,000, and there was a daily labour force account).

During the second step of the delimitation process, catchment areas were created around centres according to the most important destination (to the listed centres) of the commuting of employees. Sub-centres were merged with their dominating centre and their entire catchment area was attached also. The spatial continuity of hinterlands was formed according to the affiliation of the most important centre of attraction.

The concept of labour market areas (LMA) is applied by the so-called 'EURO method' as it has been tested by the EUROSTAT and several research groups in Europe. The objective of the EUROSTAT is to provide harmonized basis for regional taxonomy in the countries of the EU in order to detect and evaluate the processes of the labour market. In the followings, we refer to this method and its result as 'EURO method', because this version (Ichim, 2016) was applied during the current analysis.

The EURO method is a multivariate calculation developed originally by the CURDS research group. The applied and introduced method is based on the CURDS algorithm using 
the symmetrizing measure proposed by Smart (1974) - see [1]. The referred methodology became the most successful and acknowledged approach to functional regional taxonomy with considerable results from numerous countries (inter alia Casado-Díaz, 2000; FlórezRevuelta, Casado-Díaz, \& Martínez-Bernabeu, 2008; Persyn \& Torfs, 2011).

During the running process of the algorithm (supported by the statistical program R) (Ichim, 2016) the settlements are grouped as basic units. These groups are evaluated by their size (number of the economically active population) and their self-containment (the lower value from the demand and the supply side self-containment), where demand side selfcontainment (DSSC) is the ratio of intra-regional flows and the volume of incoming commuting flow, supply side self-containment (SSSC) is the ratio of intra-regional flows and the volume of outgoing commuting flow. The size and self-containment (SC) of every created settlement group (LMAs or individual settlements in this phase) are evaluated by the validity function (in which the minimum size, the target size, the minimum self-containment and the target self-containment are included). Optimization is ensured by the function as small size LMAs (above the minimum size criteria) must fulfil the criteria of higher SC. The filtered groups are disaggregated by the algorithm and the settlements are merged into the dominant group or put onto reserve list. The dominant group is identified by the following measure [1] (it is applied to make the original commuting dataset symmetrical and relativized):

[1] Smart's measure:

$$
\left[\frac{T_{i j}^{2}}{\left(\sum_{k} T_{i k} * \sum_{k} T_{k j}\right)}+\frac{T_{j i}^{2}}{\left(\sum_{k} T_{j k} * \sum_{k} T_{k i}\right)}\right]
$$

where $T_{i j}$ denotes the flow from spatial zone $i$ to spatial zone $j$, and $T_{j i}$ from $j$ to $i, \sum_{k} T_{i k}$ denotes all outgoing flows from $i, \sum_{k} T_{k j}$ denotes all ingoing flows to $j, \sum_{k} T_{j k}$ denotes all outgoing flows from $j$, and finally $\sum_{k} T_{k i}$ denotes all ingoing flows to $i$.

Smart's measure can be regarded as mathematically the most correct way to transform the interaction data (Halás, Klapka, Tonev, \& Bednáŕ, 2015). This measure decreases the dominance of larger centres and it can support the principle of spatial equity (Michniak, 2003).

The concept of functional regions (FR) is similar to the EURO method, however, it produces significantly different results. The cited studies (Klapka et al., 2014; Halás et al., 2015) refer to the method as 'CURDS measure' and this form is used in the current text. 
The main difference between the EURO method and the CURDS measure is found at the beginning of the algorithm. The process of the algorithm of the CURDS measure calculating the regional taxonomy is divided into three stages including four steps and several operations. The identification of proto-regions (identification of potential cores and identification of multiple cores by critical values of the interaction measure) is followed by the assignment of spatial zones to the proto-regions by interaction measure maximization. In the last step, the assessment of the validity of the solution is made by the application of the constraint function and iterative dissolution is applied for the regions not meeting the criteria set by the constraint function [for more details about the process see Klapka et al. (2014), Halás et al. (2015) and Pálóczi et al. (2016)].

In the regionalization process the constraint function is used in the following step to set a minimum size and self-containment criteria for the obtained regions (a continuous curve was applied during the delimitation process determined by four parameters - lower and upper limits of the self-containment, lower and upper limits of the size). The size of a region is regarded as the most general feature of a region (e.g. the number of employed people), which is a standard and easily accessible indicator. Self-containment is a vital parameter, and its value cannot be allowed to drop under 0.5 - this means that at least $50 \%$ of all interactions (commuters) to a region should occur within the region itself. The most essential outputs of the regionalization are considered by these parameters and the constraint function.

The CURDS measure was used with the demonstrated methodology for example in the case of the Czech Republic (Halás et al., 2015), Slovakia (Halás, Klapka, Bleha, \& Bednár̆, 2014) and Hungary (Pálóczi et al., 2016).

\section{RESULTS}

The three illustrated methodologies give more or less different aspects to the delimitation issue of functional regions on the basis of the commuting dataset of the census in 2011. The objective of the current study is to make a comparative research covering the three introduced methodologies focusing on the number of the obtained functional regions, especially their centres and hinterlands. It is important to emphasize that finding the optimal division is not included in this paper, so this parallel comparison does not make any attempt to indicate the 'best' division for Hungary. This issue could be the core problem of a more extended study. According to the LLS methodology 123 districts were delineated. (Fig. 1) 
Figure 1 The territorial division of Hungary based on the local labour systems (LLS) with the centres and sub-centres, 2011

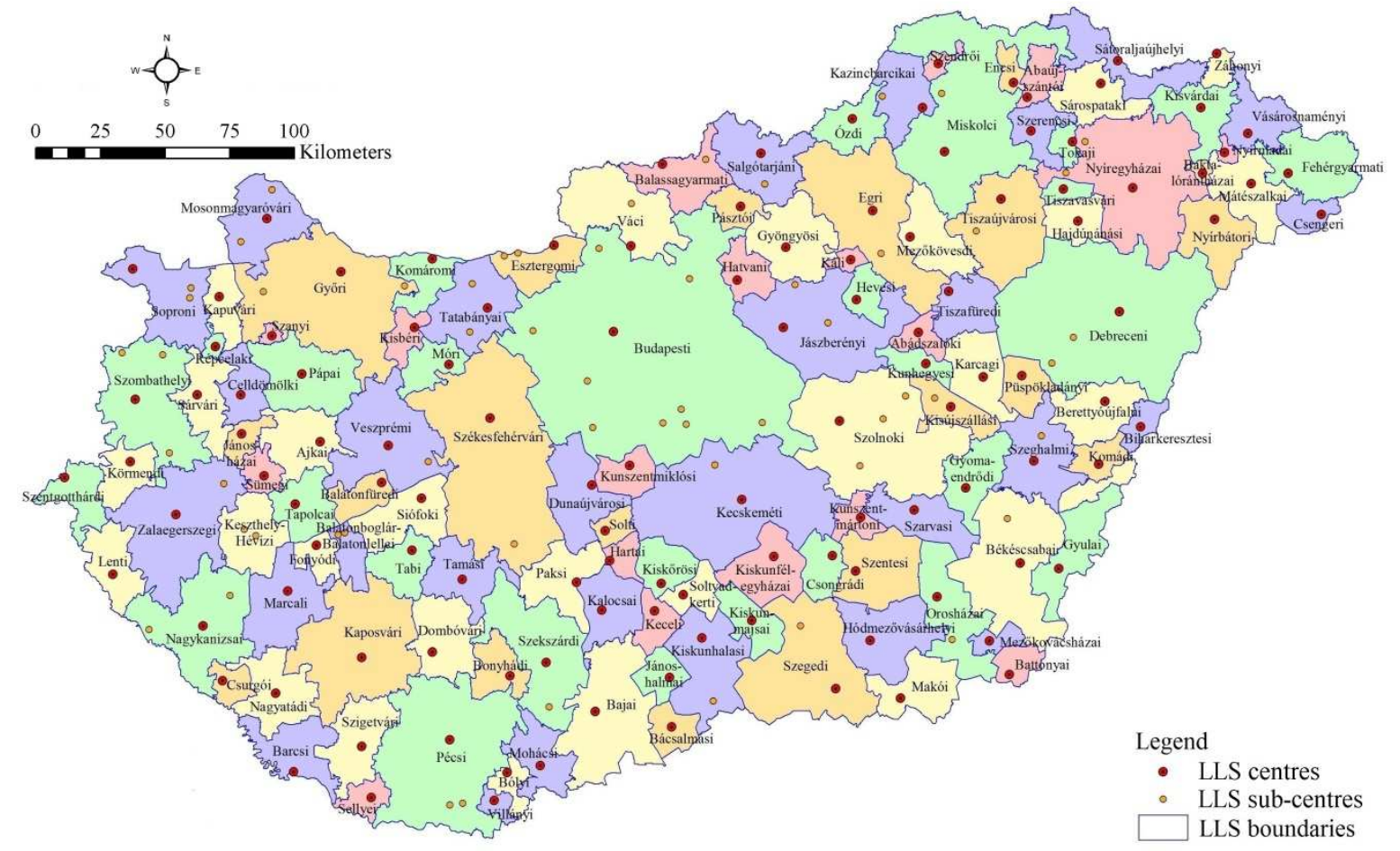

Source: by Pénzes et al. 2015, Fig. 4., p. 77.

The same parameters were applied in the case of the EURO method (Fig. 2) and the CURDS measure (Fig. 3) in order to ensure the comparative approach [these parameters were the lower (3,500 employed people) and the upper limits of the size (20,000 employed people) and the lower (0.60) and upper limits of the self-containment (0.65)]. The same variants of parameters provided the possibility to reveal the most important territorial differences between the obtained divisions (Tab. 1).

Table 1 The descriptive statistics of the results of the three methods

\begin{tabular}{|l|c|c|c|c|}
\hline Method & $\begin{array}{c}\text { Number of } \\
\text { functional } \\
\text { regions }\end{array}$ & $\begin{array}{c}\text { Average } \\
\text { number of } \\
\text { settlements }\end{array}$ & $\begin{array}{c}\text { Maximum } \\
\text { number of } \\
\text { settlements }\end{array}$ & $\begin{array}{c}\text { Minimum } \\
\text { number of } \\
\text { settlements }\end{array}$ \\
\hline LLS method & 123 & 26 & 213 & 2 \\
\hline EURO method* & 143 & 23 & 116 & 1 \\
\hline CURDS measure* & 114 & 28 & 129 & 1 \\
\hline
\end{tabular}

*calculated on the basis of the parameters detailed in the text

Source: calculated by the authors on the basis of the census data 
Figure 2 The territorial division of Hungary using the EURO method, 2011

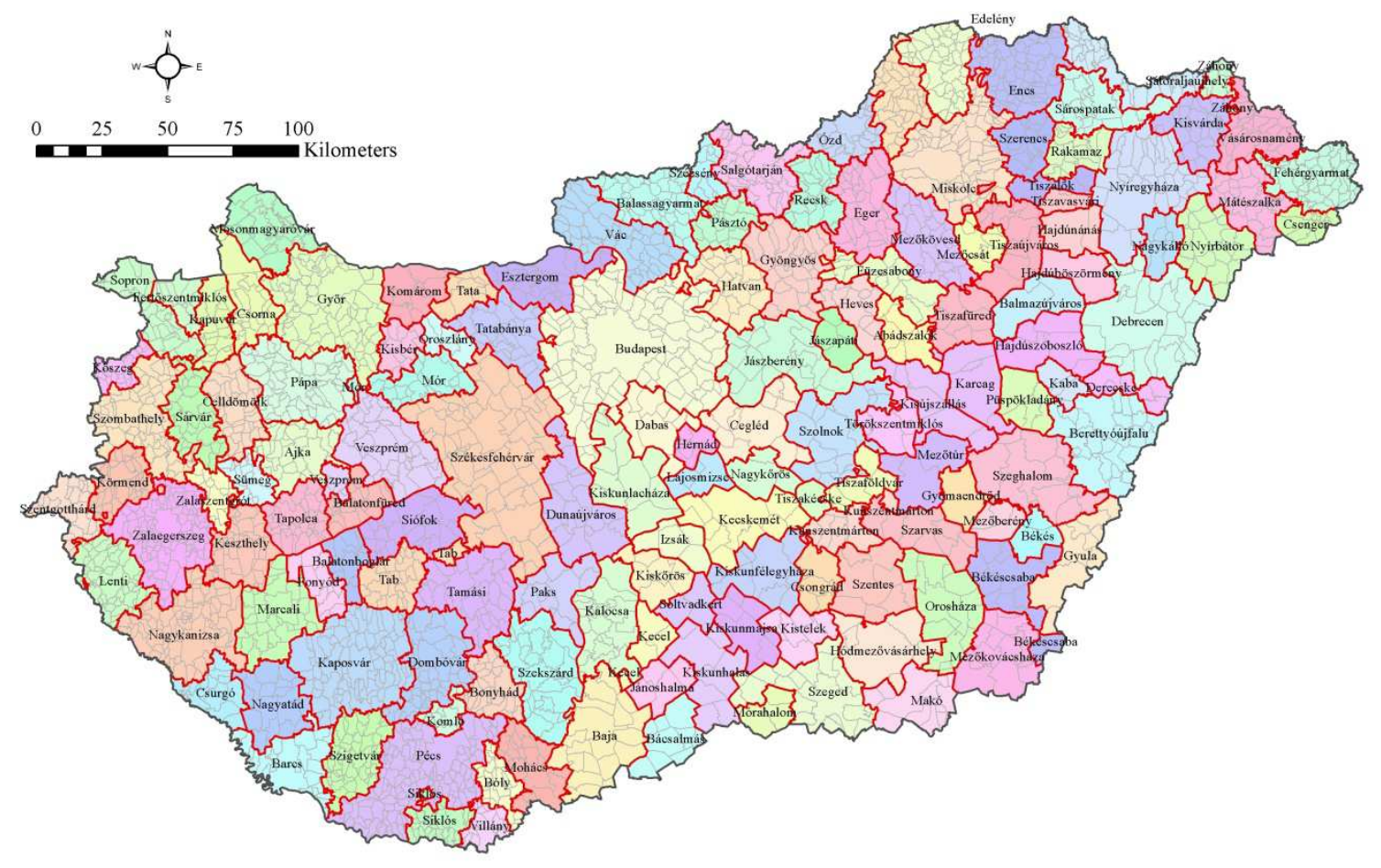

Source: edited by the authors on the basis of the census data

Figure 3 The territorial division of Hungary using the CURDS measure, 2011

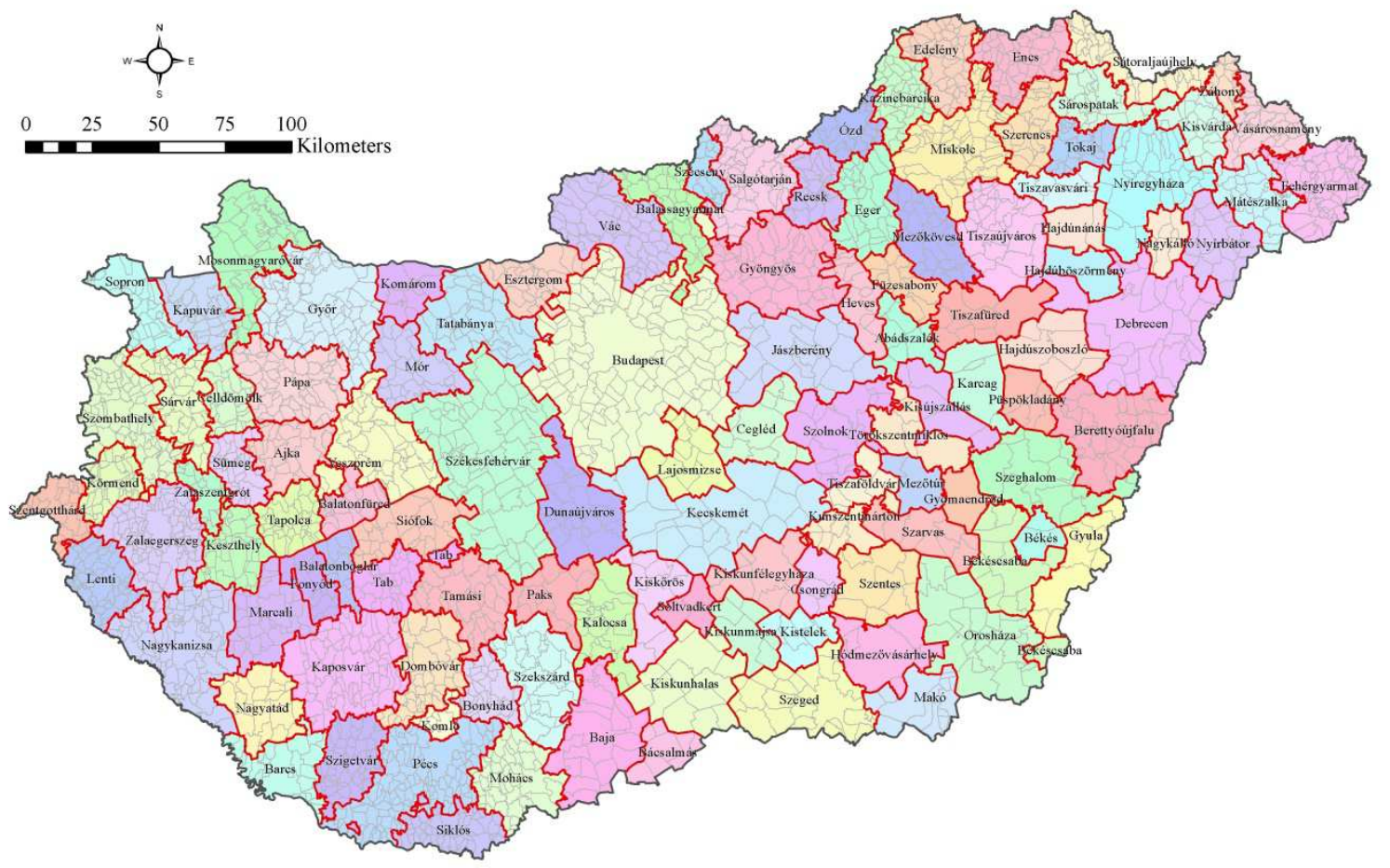

Source: edited by the authors on the basis of the census data 
Table 2 The centres and number of population of the largest and smallest functional regions according to the results of the three methods, 2016

\begin{tabular}{|l|c|c|c|c|c|}
\hline \multirow{2}{*}{ Method } & \multicolumn{2}{|c|}{$\begin{array}{c}\text { The largest functional } \\
\text { region's }\end{array}$} & \multicolumn{2}{|c|}{$\begin{array}{c}\text { The smallest functional } \\
\text { region's }\end{array}$} & \multirow{2}{*}{$\begin{array}{c}\text { Relative } \\
\text { deviation }\end{array}$} \\
\cline { 2 - 5 } & centre & $\begin{array}{c}\text { number of } \\
\text { population }\end{array}$ & centre & $\begin{array}{c}\text { number of } \\
\text { population }\end{array}$ & \\
\hline LLS method & Budapest & $2,995,463$ & Szany & 2,554 & 344.1 \\
\hline EURO method* & Budapest & $2,639,888$ & Villány & 10,568 & 324.5 \\
\hline CURDS measure* & Budapest & $2,751,570$ & Soltvadkert & 11,031 & 300.6 \\
\hline
\end{tabular}

*calculated on the basis of the parameters detailed in the text

Source: calculated by the authors on the basis of the HCSO and census data

The major differences between the applied methods could be detected in the occurrence of smaller centres and in the extension of the largest towns' hinterlands. (Table 2 and Fig. 4) Unambiguously, Budapest produced the largest functional region by all of the methods, however, it contains 213 settlements using the LLS method (with almost 3 million inhabitants) and only 116 when the EURO method is applied (with more than 2.64 million inhabitants). The smallest functional regions were represented by Szany according to the LLS method, Villány using the EURO and Soltvadkert using the CURDS measure. Due to the most extreme values produced, largest disparity was calculated from the LLS results (applying the method of relative deviation).

Figure 4 The boundaries of functional regions obtained using the three compared methods, 2011

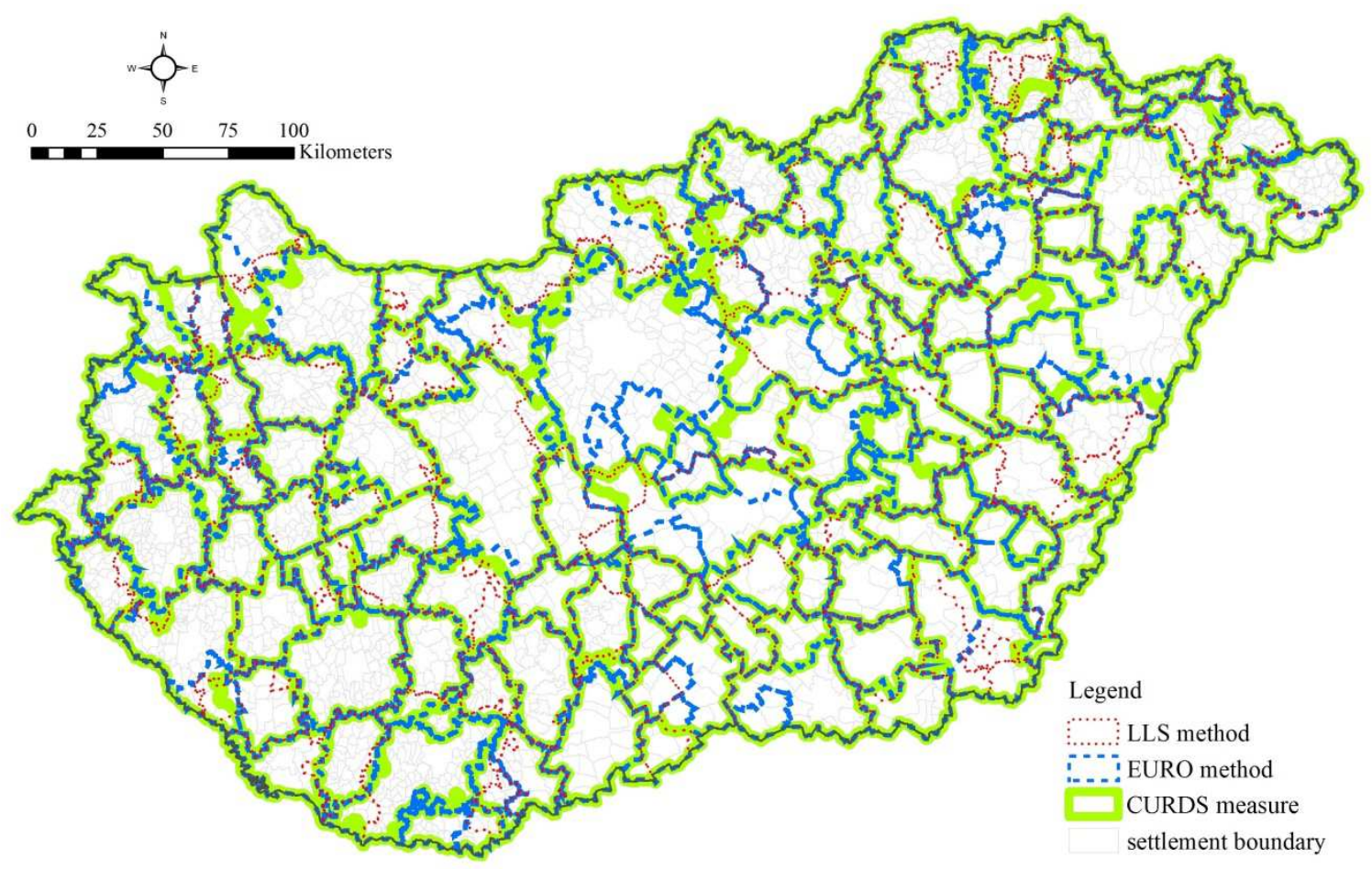

Source: edited by the authors on the basis of the census data 
The functional regions were assumed as nodal regions (apart from a few exceptional cases, the dominant part of them is a real nodal region) for the purpose of indicating one centre in every functional region. In the case of the LLS division sub-centres were neglected and only one centre was highlighted. Only one central settlement was identified (the largest one) in the EURO method and CURDS measure in order to make a simplified comparison.

Figure 5 The centres of the functional regions obtained using the three compared methods, 2011

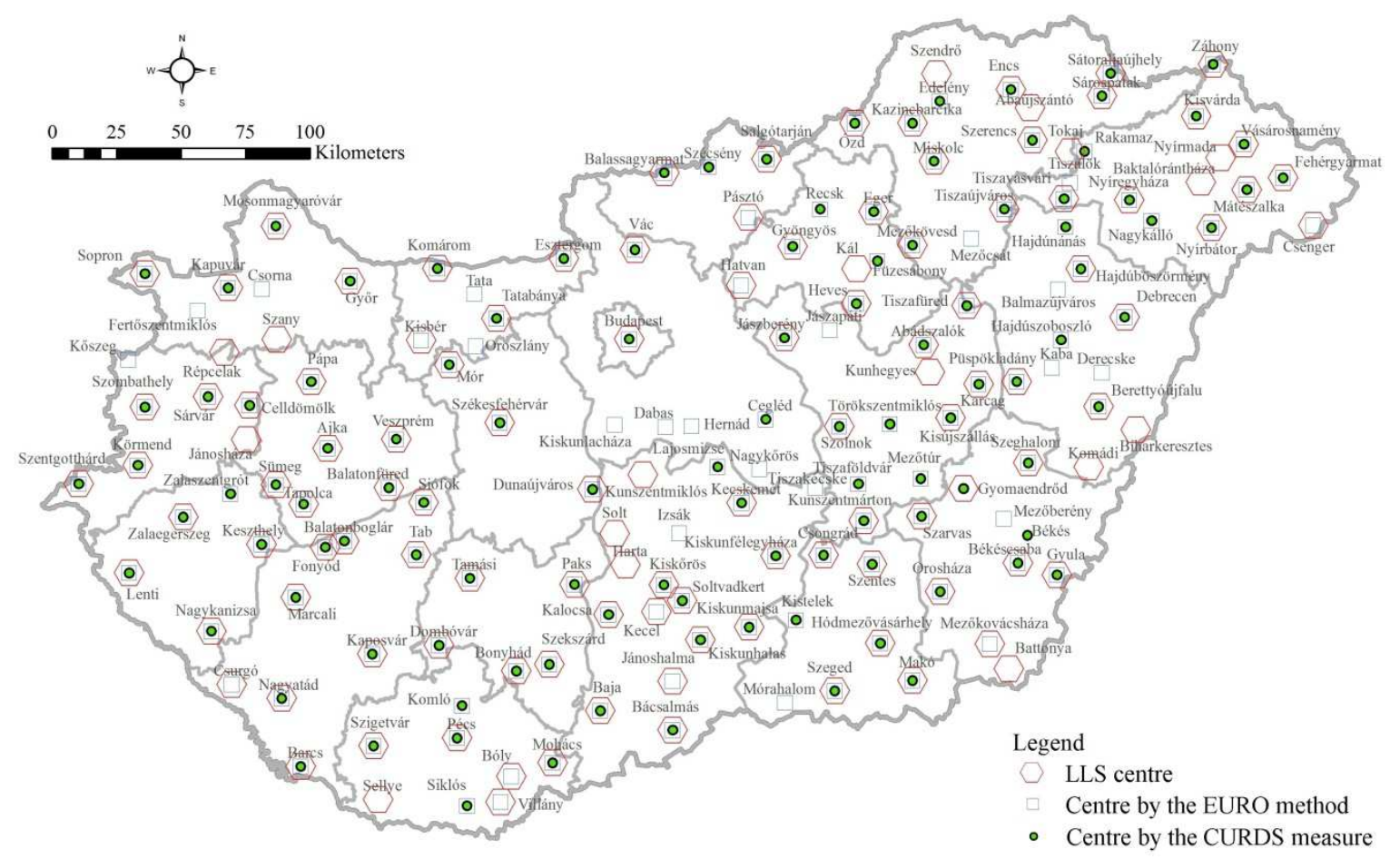

Source: edited by the authors on the basis of the census data

The centres of the functional regions demonstrated a complex territorial pattern (Fig. 5). The centres of the EURO method - as it was stated - appeared with the largest frequency. Those centres were regarded more dominant that were delimited by all of the methods. This list contained 96 centres - each centre had a town rank (by the Hungarian administrative division) including Budapest and the county seats (in 2016).

28 centres were indicated by two of the methods (all of them were delimited by the EURO method) - Recsk is a large village from them. 36 centres appeared in the results of only one of the methods. The CURDS measure produced only those centres that were delineated by at least one more method.

The different characters of the methods were clearly demonstrated by the obtained maps (Fig. 4 and Fig. 5). The appearance of the LLS centres indicated the polarizing character of the method resulting in an outstanding dominance of the largest centres (first of all to 
Budapest and the largest towns as well), at the same time it gave possibility to the smaller centres to be delimited. Centres in the peripheral areas (e.g. Abaújszántó, Baktalórántháza, Komádi, Nyírmada, Sellye, Szendrő) or in territories without large centres (e.g. Jánosháza, Harta, Solt, Szany) might also appear.

The EURO method characteristically gave the possibility for those centres to appear locating them in the surroundings of dominant centres (e.g. in the agglomeration of Budapest, Debrecen or Tatabánya). Balmazújváros, Dabas, Derecske, Hernád, Kaba, Kiskunlacháza, Oroszlány, Tata, Csorna and Köszeg are the most typical examples.

The CURDS measure was the "strictest" one - for instance Pest, Fejér, KomáromEsztergom and Nógrád counties (in the neighbouring territories in the proximity of Budapest) contained only three centres, including the capital city itself.

The NUTS 3 units of Hungary (19 counties and Budapest) could be described very varied from the aspect of the summarized results of the centres. Some of the counties were absolutely homogeneous considering the delimited centres - all of the three methods gave the same results regarding centres in the case of Fejér, Tolna and Veszprém counties. The results for Nógrád, Somogy and Zala counties could be regarded as stable enough. However, the remaining counties represented more or less significantly differing spatial patterns that made the comparative analysis difficult and the selection of the appropriate method expressively complicated (or almost impossible).

\section{DISCUSSION}

Territorial division based on labour market relations can be realized with various methods and variants within them. The demonstrated methods are all applicable in a given context for Hungary, however, the resulted territorial divisions and centres might be ambiguous.

The appropriate method should produce a territorial division that reflects the geographical characteristics, the settlements' structure, the number of relations and the intensity of flows. The LLS methodology is too 'rigid' to give more alternative variations of the results, in contrary to the EURO and CURDS measures.

It is important to keep the objective of the delimitation in mind. Several delimitations are determined by previous divisions or by the number or boundary of administrative units (Casado-Diaz, 2000). The extent of the obtained functional regions can also be limited by intervals (ISTAT 2014). The aim of the research could be to find an optimal solution after a heuristic and iterative process. The selection is most frequently based on the given set of 
descripting indicators. However, this problem is the most significant disadvantage of the EURO and CURDS measures (Thorsen, 2017).

The tested and compared methods all provide reasonable results that can be appropriate in given conditions. The characteristic behaviour of the methods can be traced in the occurrence of centres and their hinterland boundaries. However, not only the methods can be tested in this way but the role of the centres can also be investigated. The role of towns is a complex and always actual issue (Demeter-Radics, 2009; Nagy, 2010; Csomós, 2015; Bujdosó et al., 2016). This approach contains only the nodal role of centres (primarily towns) from the aspect of commuting to work, however, the results may significantly overlap with other town ranks (this issue is not included into the current study).

\section{CONCLUSION}

The current paper demonstrated three different territorial divisions on the basis of the LLS method, the EURO method and the CURDS measures. The differing characters of the calculations demonstrate the polarizing character of the LLS method. The EURO method results in less extended functional regions in the case of the larger centres compared to the CURDS measure using the same set of parameters.

The centres of the delimited functional regions are primarily nodal centres as well. The rest can be unambiguously defined as important employment centres because all of the methods indicated their important role. The methods of functional regionalization differ from each other in the different 'treating' of peripheral areas with limited flows and in the extent of functional regions with large centres (e.g. Budapest). The investigation also indicates the counties with relatively stable centres and functional regions around them.

The current study is very specific due to the basic dataset and methodology that is why the demonstrated results should be interpreted only in this context.

\section{SUMMARY}

The current paper deals with the topic of functional regionalization and demonstrates some of the possible delimitation methodologies on the basis of commuting to work dataset provided by the 2011 census in Hungary. The main objective of the study is to compare the results of the different methods based on the delimited territorial divisions and the centres occurred.

The method of local labour systems (LLS) is a two-step hierarchical methodology giving special emphasis on the nodal approach, in which the centres are clearly identified. The EURO method and the CURDS measure are also based on the flows of employees but nodal centres are defined only by the most populous settlements within the functional regions. These methods seem to be similar but after going into details significant differences can be discovered. The results of the calculations clearly demonstrate the different character of the methods. 
The LLS method results in 123 units with major disparities significantly polarizing the outlined spatial units with Budapest LLS including almost 3 million inhabitants. The EURO method results in the less extending central region around Budapest, however, the CURDS measure causes the most moderate inequalities among the functional regions with the least number of units.

The differing character of the methods can be discovered in the centres as well. The occurrence of the LLS centres indicates the polarizing character of the method resulting in the outstanding dominance of the largest centres, at the same time it makes the delimitation of smaller centres possible. Centres in the peripheral areas or in territories without large centres may also occur. The centres of the EURO method occur with the largest frequency because this method characteristically makes the delimitation of centres located in the surroundings of dominant centres possible. The CURDS measure is the 'strictest' one from this aspect.

There is a significant overlap in the results - 96 centres are delimited by all of the three methods and 64 by one or two of the methods. Some of the Hungarian counties are absolutely homogeneous regarding the delimited centres, every method give the same result about centres in the case of Fejér, Tolna and Veszprém counties.

Each method provide appropriate results from a given perspective, however, the calibration of the methods with four parameters (EURO method and CURDS measure) are not among the objectives of the current study.

\section{Acknowledgement}

The current research was supported by the project of the Eurostat and the Hungarian Central Statistical Office (project number: 08141.2015.001-2015.500)

\section{REFERENCES}

Bujdosó, Z., Dávid, L., \& Uakhitova, G. (2013). The effect of county border on the catchment area of towns on the example of Hajdú-Bihar County - methodology and practice. Bulletin of Geography. Socio-economic Series, 22(22): 21-33.

Bujdosó, Z., Kovács, T., Szücs, C., \& Branbauer, Z. (2016). "New" direction of urban development from a Central European perspective. Theoretical and Empirical Researches in Urban Management, 11(2): 55-64.

Casado-Díaz, J. M. (2000). Local Labour Market Areas in Spain: A Case Study. Regional Studies, 34 (9): 843-856.

Coombes, M., Green, A. E., \& Openshaw, S. (1986). An Efficient Algorithm to Generate Official Statistical Reporting Areas: The Case of the 1984 Travel-to-Work Areas Revision in Britain. The Journal of the Operational Research Society, 37(10): 943-953.

Coombes, M., \& Bond, S. (2008). Travel-to-Work Areas: the 2007 review. London: Office for National Statistics

Csomós, G. (2015). The ranking of cities as centres of the Hungarian economy (1992-2012). Regional Statistics, 5(1): 66-85.

Demeter, G., \& Radics, Z. (2009). Centrumok és perifériák a Monarchia szétesése után - az új határok racionalitásának vizsgálata gravitációs modellek alapján [Centres and peripheries after the disintegration of the Dual Monarchy]. Közép-európai Közlemények, 2(2-3): 151-160.

Flórez-Revuelta, F., Casado-Díaz, J. M., \& Martínez-Bernabeu, L. (2008). An Evolutionary Approach to the Delineation of Functional Areas Based on Travel-to-work Flows. International Journal of Automation and Computing, 5 (1): 10-21.

Haggett, P. (1965). Locational analysis in human geography. London: Edward Arnold.

Halás, M., Klapka, P., Bleha, B., \& Bednář, M. (2014). Funkčné regióny na Slovensku podl’a denných tokov do zamestnania [Functional regions in Slovakia according to daily travel-to-work flows]. Geografický časopis/Geographical Journal, 66 (2): 89-114. 
Halás, M., Klapka, P., Tonev, P., \& Bednář, M. (2015). An alternative definition and use for the constraint function for rule-based methods of functional regionalisation. Environment and Planning A, 47: 1175-1191.

Ichim, D. (2016). The $R$ package LabourMarketAreas. [Presentation]. Retrieved from: https://ec.europa.eu/eurostat/cros/system/files/the_r_package_labourmarketareas.pdf

ISTAT (2014). Nota metodologica. Sistemi Locali del Lavoro [report]. Retrieved from: http://www.istat.it

Karlsson, C., \& Olsson, M. (2006). The Identification of Functional Regions: Theory, Methods, and Applications. The Annals of Regional Science, 40(1): 1-18.

Klapka, P., Halás, M., \& Tonev, P. (2013). Functional Regions: Concept and Types. In, 16th International Colloquim on Regional Science. Conference Proceedings (Valtice 1921.6.2013). Brno: Masarykova Univerzita: 94-101

Klapka, P., Halás, M., Erlebach, M., Tonev, P., \& Bednáŕ, M. (2014). A Multistage Agglomerative Approach for Defining Functional Regions of the Czech Republic: The Use of 2001 Commuting Data. Moravian Geographical Reports, 22(4): 2-13.

Laan van der, L., \& Schalke, R. (2001). Reality versus Policy: The Delineation and Testing of Local Labour Market and Spatial Policy Areas. European Planning Studies, 9(2): 201221.

Michniak, D. (2003). Dostupnost' okresných miest na Slovensku [Accessibility of district centres in Slovakia]. Geografický časopis, 55(1): 21-39.

Nagy, Z. (2010). The Development of Regional Centres in Hungary in the past two decades. European Integration Studies, 8(1): 107-131.

Nystuen, J. D. \& Dacey, M. F. (1961). A graph theory interpretation of nodal regions. Regional Science Association, Papers and Proceedings, 7, 29-42.

Pálóczi, G., Pénzes, J., Hurbánek, P., Halás, M., \& Klapka, P. (2016). Attempts to delineate functional regions in Hungary based on commuting data. Regional Statistics, 6(1): 2341.

Pénzes, J., Molnár, E., \& Pálóczi, G. (2015): Local Labour System after the turn of the millennium in Hungary. Regional Statistics, 5(2): 62-81.

Persyn, D., \& Torfs, W. (2011). Functional Labour Markets in Belgium: Evolution over time and intersectoral comparison. Discussion Paper 17. Leuven: Katholieke Universiteit, Vlaams Instituut voor Economie en Samenleving.

Philbrick, A. K. (1957). Principles of areal functional organization in regional human geography. Economic Geography, 33(4): 299-336.

Radvánszki, Á., \& Sütő, A. (2007). Hol a határ? Helyi munkaerőpiaci rendszerek Magyarországon - Egy közép-európai transznacionális projekt újdonságai a hazai településpolitika számára [Where is the border? Local Labour Systems in Hungary Novelties of a Central-European transnational project to the Hungarian settlement policy]. Falu Város Régió, 14(3): 45-54.

Smart, M. W. (1974). Labour market areas: uses and definition. Progress in Planning, 2(4): 239-353.

Thorsen, T (2017). Labour Market Areas in Denmark. [Presentation] LMA Meeting in Paris. 26-27. January 2017. 